\title{
FURIN wt Allele
}

National Cancer Institute

\section{Source}

National Cancer Institute. FURIN wt Allele. NCI Thesaurus. Code C49715.

Human FURIN wild-type allele is located in the vicinity of $15 q 26.1$ and is approximately 15

$\mathrm{kb}$ in length. This allele, which encodes furin protein, plays a role in the cleavage of

proteins containing paired basic amino-acid residues to release mature proteins from their precursor proteins. 